\title{
PRINCIPLES OF THE FRENCH GARDEN IN THE CZECH GARDEN DESIGN
}

\author{
Anna Magni ${ }^{1}$ \\ ${ }^{1}$ Department of Garden and Landscape Architecture, Faculty of Horticulture, Mendel University in Brno, \\ Zemědělská 1, 61300 Brno, Czech Republic
}

To cite this article: MAGNI ANNA. 2018. Principles of the French Garden in the Czech Garden Design. Acta Universitatis Agriculturae et Silviculturae Mendelianae Brunensis, 66(5): 1171-1181.

To link to this article: https://doi.org/10.11118/actaun201866051171

\begin{abstract}
The French garden of the 17th and 18th century as the ultimate artistic expression of ideas about the world order and the representation of power and knowledge was not limited to its country of origin - its influence spread and appeared all over Europe. The following text focuses on its reflection in the territory of the Czech Republic and follows the ways the main principles of this form of garden design took. Besides the traditionally dominant artistic influence of Italy, the French art was reflected only gradually, and above all, indirectly. Activities of Le Nôtre's disciples have been proven, but without any more detailed documentation. Moravia was most influenced by Vienna, where the imperial and other aristocratic gardens adopted more ornate, smaller and flatter concept of French forms, rather approaching Rococo.

The paper shows, using specific examples and the comparative method, what forms typical of the French garden appear in the gardens of the Czech lands the most frequently. The characteristic organization of the garden and wider spaces by axes, avenues, radial divisions, water mirrors and canals as well as magnificent water elements with sculptures and also widely applied flat parterres with ornamental flower beds is explored. On the other hand, the complexity of the French prototype, which lies in the spatial monumentality and sophisticated use of optical rules and rules of perspective, is missing.
\end{abstract}

Keywords: French garden, Czech garden design, Baroque, Classicism, Le Nôtre

\section{INTRODUCTION}

While the theory of art and history of culture distinguish individual artistic styles, it is more appropriate in some cases that the history of garden design distinguishes various development stages of a garden based on its affiliation to the main geographical patterns, the main currents, which appeared in the history of European garden culture and spread in different variations and later combinations beyond the boundaries of their origins. So instead of the Baroque or classical garden, it is more accurate to specify whether the garden follows the Italian or French design, or whether it changed in the course of its development under the influence of the English landscape garden ${ }^{1}$. Out of the three mentioned main European prototypes ${ }^{2}$

1 The same classification is used in e.g.Z. Wirth(1911), influences of the Italian and French Garden are consistently distinguished by Z. Dokoupil et al. (1957).

2 By prototype prof. Jiří Damec means garden design of a specific period and territory formed into a fixed shape with typical features. In the European context, the prototypes are the Italian garden (corresponding to the period of the Renaissance), the French garden (the style classification is described further in the text), and the youngest English landscape garden. 
reflected in garden design, i.e., the Italian garden, the French garden and the English landscape garden, the following review focuses on the middle of them: As in other periods, the French Baroque ${ }^{3}$ garden, at its climax in the second half of the 17th century represented especially by the work of André Le Nôtre (1613-1700), was based on a number of sources: in its early days it absorbed the Italian designs from the arriving Italians and it got inspiration from the (often overlooked) Dutch garden (Wirth, 1911; Bouchenot-Déchin, 2013), especially with its flat ornamentation and use of water in the form of enclosing and intersecting canals. It took the geometric connection of the house and the garden from Italy, retained the Greco-Roman pantheon as inspiration for the sculptures, applied the geometric floral compositions and the spectacular water features. However, the concept of space changed under Le Nôtre's hands in France: the garden and its main axis were extended, the perspective was used in a sophisticated manner, and the terrain was modified so that the views went to infinity. The vastness was mirrored in static water canals and pool surfaces. In this spirit, Le Nôtre, certainly under the influence of the painter's education he obtained from the landscape painter Simon Vouet, stepped over the boundaries of the garden space (in Italy still sharply defined and divided into squares), and linked it with the surrounding landscape.

Although he did not publish any theory, the great wave of the French garden fashion propagated already during his life. Aristocrats, artists and craftsmen brought their personal experience from their grand tours over France. Le Nôtre's work became well-known also thanks to engravings depicting his creations and as postcards travelling across Europe. After his death in 1700, his work was diffused by Dezallier d'Argenville's text complemented with engravings by Jean-Baptiste Alexandre Le Blond ${ }^{4}$, which were present in many rulers' and nobles' libraries throughout Europe. The text and the illustrations present the ideal garden composition and its fundamental components. Together with the old plans of Le Nôtre's gardens, he provides a perfect idea about the French garden prototype.

The following text explores how the prototype of the French garden was reflected in the Czech lands, how its echoes came there, whether it was applied in its complexity and dazzling magnificence, or rather, partial elements and details were incorporated. The first reflections of the French garden in the Czech territory from the end of

I: List of studied sources (old books and archive documents) mentioned in the article

\begin{tabular}{|c|c|c|c|}
\hline $\begin{array}{l}\text { Name of the garden/ } \\
\text { Name of the document }\end{array}$ & Date & Author & Source \\
\hline $\begin{array}{l}\text { La théorie et pratique } \\
\text { du jardinage (...) }\end{array}$ & 1709 & Dezallier D’Argenville & gallica.bnf.fr/Bibliothèque nationale de France, p. 43 \\
\hline $\begin{array}{l}\text { Jaroměřice } \\
\text { and Rokytnou }\end{array}$ & 1732 & Nicolaus Millich & $\begin{array}{c}\text { Castle collection Jaroměřice nad Rokytnou. } \\
\text { Sign. JR05822 }\end{array}$ \\
\hline Royal Garden, Praha & 1704 & & DOKOUPIL, Z. et al. 1957. N. 16 \\
\hline Český Krumlov & 1796 & Jean Louis Le Rouge & $\begin{array}{l}\text { Cahiers des jardins anglo-chinois } \\
\text { DOKOUPIL, Z. et al. 1957. N. } 71\end{array}$ \\
\hline Trója & About 1740 & & Exposition at the Troja Palace \\
\hline Červený dvůr & $\begin{array}{l}\text { 2nd half of } \\
\text { 18th century }\end{array}$ & & DOKOUPIL, Z. et al. 1957. N. 72 \\
\hline Lednice & 1789 & Karl Rudzinsky & $\begin{array}{l}\text { KREJČIŘÍK, P. 2015. Development and interpretation } \\
\text { of castle garden in Lednice. [Online]. Available at: } \\
\text { http://web2.mendelu.cz/zf_563_krarch/1.3.1_MAPY- } \\
\text { k-metodice-Architektonicko-historicky-pruzkum- } \\
\text { pamatek-zahradniho-umeni_Lednice/1_MAPY_Vyvoj- } \\
\text { zameckeho-parku-v-Lednici. }\end{array}$ \\
\hline Dobříš & By 1770 & Karel Saltzer & WIRTH, Z. 1938. P. 67 \\
\hline Slavkov u Brna & 1732 & Wenzel Petruzzi & Brno city archive, archive n. 26. V3. sign. A 260, n. 42/2 \\
\hline Holešov & 1750 & & $\begin{array}{l}\text { Private collection of Jiří Dohnal, } \\
\text { photo: Barbora Havelková }\end{array}$ \\
\hline Lužánky, Brno & 1812 & & $\begin{array}{l}\text { MZA Brno, Collection of Maps and Plans, Paper } \\
\text { Directory File II/l, File Number } 1357\end{array}$ \\
\hline
\end{tabular}

3 Professional and popular literature use more terms, which all indicate the same thing. The French literature uses the term Baroque garden for the garden of the 17th century (e.g. Baridon 2002), but we can encounter terms like the French garden, the Baroque garden, the Baroque-classical or neo-classical garden.

4 La théorie et pratique du jardinage published for the first time in 1709.

5 Available online at the French National Library (Source gallica.bnf.fr/Bibliothèque nationale de France).

6 Also online, see footnote 5 . 
the 17th century will be searched for and their development until the beginning of a new style, the period when the first landscape gardens were established, will be followed.

It focuses on gardens at palaces, castles and chateaus and the stages in their development that are documented, regardless of the extent to which they have been preserved, as a whole or in elements, until the present day. The text and the illustrations present the ideal garden composition and its fundamental components. Together with the old plans of Le Nôtre's gardens, he provides a perfect idea about the French garden prototype. The aim is not to name all of the examples of the French principles applied in the territory; rather, to highlight the examples that are significant, exceptional or representative, either as a whole or in details.

\section{MATERIALS AND METHODS}

First of all, the sources for the following text - professional Czech and French texts about building and architecture, sculptures, and garden design of the Baroque and classicism are explored as regards the relations between the French and the Czech environment, the ways of the prototype transfer and other influences. Secondly, archive documents are studied, in particular the old plans, partly also with historical veduttas. Mainly old plans of French gardens, such as Vaux-le-Vicomte and Versailles ${ }^{5}$, and model schemas in Dezallier's theoretical writings ${ }^{6}$ are investigated. The available and published historical documentation of selected garden complexes in the territory of the Czech Republic is compared with focus on compositional principles of garden complexes and the solution of their individual parts, such as the vegetation (broderie parterres, bosquets, lawns, avenues), water features (canals, water mirrors), but also the garden relationships with the architecture and the surroundings or terrain conditions and the perspective. An indispensable source is the author's own explorations of the gardens in situ.

\section{RESULTS}

\section{Mediation of the French prototype, influence of Vienna}

Despite the geographical distance between the Czech Republic and France, there are documents of the specific and direct spreading of le Nôtre's principles of garden design and landscape formation, as well as the overall atmosphere. Similarly to France, a house with the garden represent power, influence and wealth, are the scene of social life and reflect the owner's interpretation of this world. To meet these objectives, some customers - aristocrats ordered garden designs directly from Le Nôtre's disciples. One of them, the Frenchman Jean Trehet (1654-1740), was engaged by the Imperial Court in Vienna, became the imperial garden engineer and was in charge of the design of the garden at the imperial residence Schönbrunn (from 1695). Soon after that, this garden designer worked in Moravia. He designed the palace garden with water canals for the Questenberk family in the cultural heart of Baroque Moravia, Jaroměřice nad Rokytnou. In the overall composition, shown in the ideal view of the palace and garden from 1732 (see Fig. 1), Le Nôtre's principle is found in the main axis supported by circular pools, lined with flat broderie parterres, going into the landscape and vanishing to infinity accompanied by avenues. The design uses water in a unique way; the water is brought by canals from the Rokytná River: the wide canal forms a water mirror on the transverse axis behind the longitudinal parterre in front of the palace facade, a water canal flows around a triangular island which serves as a natural theatre on the main axis.

It is also evidenced that another significant garden designer stayed in Jaroměřice. He likely worked at other places of Moravia and Silesia (Kroupa, 2006). He was Dominique Girard, active in France as well as in gardens of Nymphenburg and Viennese Belvedere.

Another Frenchman, son of Le Nôtre's direct disciple ${ }^{7}$, the landscape architect Ernest August Charbonnier (1677-1747), made the design of the garden around the palace in Moravian Židlochovice and he managed the construction there until 1714 (1715). Though a more accurate appearance of the Židlochovice garden is only known from historical descriptions, its former significance and connection to the French models is illustrated by the presence of renowned artists: new findings show that the French royal architect Robert de Cotte worked there (Šubr, 2004).

It could be expected that the type of the French representative and magnificent garden will be found in the Royal City of Prague; however, the situation is different. Traditionally, there were entire families and generations of Italian artists and craftsmen, whose influence was determining from the first half of the 16th century to the end of the 18th century (Wirth 1938, p. 59). They enriched Prague with the Italian form of the Baroque; additionally, due to the topography of Prague, the flat French garden type appeared rather marginally. It can be found ${ }^{8}$ in some details of the Royal Garden at the Prague Castle, which was reconstructed in cooperation of K. I. Dienzenhofer and the gardener F. Zinner jr. (1737-1742). The Baroque reconstruction (captured

7 His father, Martin Charbonnier, Le Nôtre's disciple knowledgeable of the Dutch garden as well, was a garden master in the garden of Herrenhausen (1668-1718) at Hanover, and he worked there with his son Ernst August (Hatton 2001, Kroupa 2004).

8 It can be found also e.g. in the garden around the Sternberg Villa in Troja, mentioned below. 
on the illustrations of 1744, see Fig. 2) shows a layout with two elongated axes. One of them is connected to the entrance over the Prašný most (Dust Bridge), the other one starts at the opposite Queen Anne's Summer Palace; they form an obtuse angle and are lined with typical elements corresponding to the French type: rich ornamental flower bed parterres in two fields, shaped bosquets, pools with sprays, and shaped arbours.

The royal court and aristocratic families as the main builders of gardens ${ }^{9}$ always maintained artistic relationships with the main European centres, in the 17th century, grand tours of nobles and artists became common. The artists worked for various clients at many estates, and also artisans travelled for experience. A powerful source of inspiration was Vienna. Especially for Moravia it was a natural and close centre of art: the Italian influences mixed there and the garden design started to be dominated by the style of high French garden. Its most representative example is the garden at the Imperial Palace in Schönbrunn, built from the end of the 17th century and completed around 1770. Its oldest form from
1695 is associated with the above mentioned Jean Trehet (Kroupa, 2004). Its development stages manifest the gradual simplification of the main principles and diminution of motives, typical of Rococo. Regarding the influence of the Viennese environment on the Czech garden design, either Moravian or Bohemian, there were two basic ways of transfer of the French garden fashion to the Czech lands. Artists who learnt the French models in the culturally and geographically near Vienna were employed in aristocratic residences. The situation is well illustrated by the example of Johann Anton Zinner (1698-1763). The Viennese sculptor, who worked in Schönbrunn, was significant for Český Krumlov, where he helped reconstruct the garden of the residence. The Schwarzenbergs invited two of the Viennese artists there and the architecture and the palace garden thus received stimuli of European significance (Mertenová, 2011). In the second half of the 18th century, the architect, Andrea Altomonte, who gained knowledge when creating the garden in Schönbrunn changed the composition of the palace garden designed the reconstruction of the Bellaria Pavilion and the terrace, where he

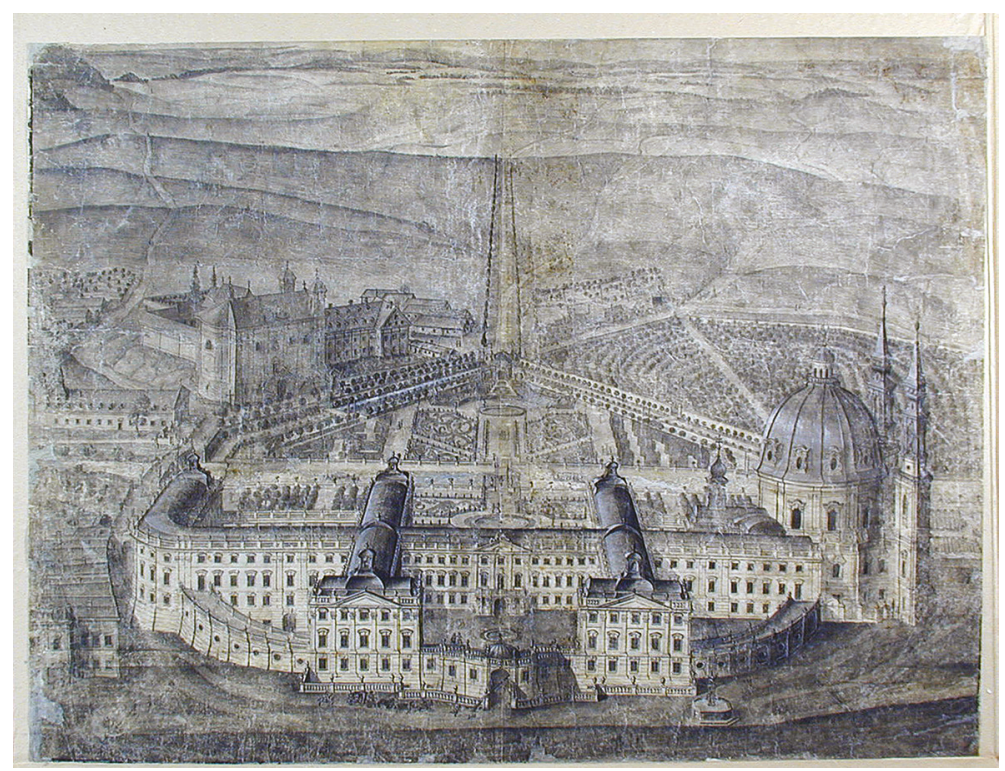

1: Jaroměrice nad Rokytnou, ideal view of the palace and garden. Nicolaus Millich, 1732.

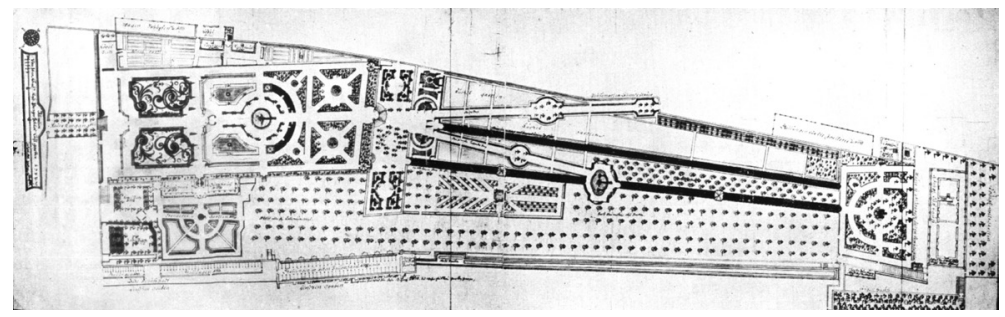

2: Royal Garden at the Prague Castle, 1744.

9 No less important builders were friaries; however, their monastic gardens represent a separate and an extensive topic for the garden design theory, which goes beyond the scope of this text. 
incorporated the Neptune Fountain and richly decorated pools, cascades and balustrades. Their author was J. A. Zinner, later appointed duke's inspector of Swarzenberg gardens. The garden after the modifications at its most magnificent stage is captured in the detailed plan (Fig. 3) in publication Cahiers des jardins anglo-chinois (Jean Louis Le Rouge, 1776). It shows the division with the main axis in the longitudinal direction, which had remained from the early Baroque stage (Pavlátová et al., 2004). In the main axis, bosquets with various internal program and organization alternate with sunny parts with flower beds, which testify to the knowledge of the French prototype. However, the ingenious mastery of the perspective and the magnificence of optical delusions are missing. The difficult terrain configuration led to a separate position of the buildings of the palace and the garden (however, smaller buildings were built directly in the garden, out of which the Bellarie Summer Palace situated on the transverse axis is the most spectacular) and either, it did not allow a direct connection with the surroundings. The garden is surrounded by a wall and the missing direct links are replaced by views of the surrounding landscape, first over a lowered part of the wall and second through two windows broken into the wall. Besides the Český Krumlov garden, J. A. Zinner worked in the garden of the Sinzendorf counts in Židlochovice, probably designed the garden in Milotice owned by the Serény family (his stay there is documented in 1716 (Krsek et al., 1996, p. 238)) and changed the Questenberk garden in Jaroměřice. As shown in Zinner's example, the connection between the Court and the nobility as the main builders and owners of gardens with the artists from Vienna was completely natural in the 17 th and the 18th centuries.

\section{Personal contacts of builders with France}

Another possible connection with the French environment was the owner's personal or power relationship with France. A unique example in this respect is the castle with a garden in Nové Hrady near Chrudim, where the owner, count Jan Harbuval-Chamaré, came from France. His artistic orientation and his own ideas were directly reflected in the form of the complex, because he personally, as an amateur architect, designed the concept of the castle building. The garden was created a little later after the completion of the castle, during 1791-1807, which was the time when new fashion had come to garden design and first landscape gardens had been established. The Nové Hrady garden still bears French features, though somewhat diminutive, with more complex and playfully decorative flower beds, as is typical of Rococo.

Travels to France for various reasons and personal ties with this country, its culture and art were common for many members of noble families based in Bohemia or Moravia. Let us name, for example, the Černín family of Chudenice - out of which Franz Joseph's (1697-1733) relationship with France included good knowledge of the language and experience with travels there in a role of a cavalier. The French influence was significantly manifested in their estates, both in the architecture of their palaces and the form of their gardens. For example, in the palace garden Krásný Dvůr, the Baroque stage of development, despite a later dramatic stylistic conversion, has left a typical trident of avenues as a link of the palace with the landscape. Another example is a gardener Živsa sent abroad to personally study Le Nôtre's work (e.g. Dokoupil, 1957). After his trip to Paris, he built a Baroque palace garden for the Kinsky family in Choceň, with the axis going through a perpendicularly divided parterre and continuing with an avenue to the landscape.

\section{Compositional elements and principles}

It is indisputable that elements typical of the French garden, as described by Dezallier, can be found in the territory of the Czech Republic: parterres with floral ornaments, clipped bosquets with internal program, grassy boulingrins. There are also pavilions, trellises, fountains, greenhouses and orangeries, sculptural figural decoration representing the antique deities, decorative vases. Generous water canals on the transverse, or even the main longitudinal axis, are rarer. Garden plans of Jaroměřice and Slavkov u Brna show a motive originally grasped. The water canal in Troja, Prague, is replaced with the Vltava River, to which the garden descends, opening to it by a grate in the enclosure wall. A water canal on the transverse axis can be found in the garden at the Baroque palace in Liblice, where also other features of the French garden can be found, though in an intimate, minor scale: a palace with a pronounced Court of Honour is elevated on a substructure, the main axis descends from it to the lowest canal and continues along a clearing in the forest.

It is also necessary to explore how these elements are grouped, where are located relative to the palace buildings, terrain conditions and their surroundings.

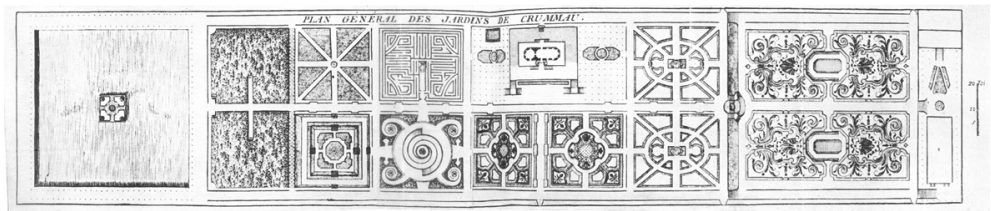

3: The disposition of the Garden in Český Krumlov, Jean Louis Le Rouge, Cahiers des jardins anglo-chinois, Paris, 1796. 
On the basis of these relationships, the influence of the French prototype can be detected. Dezallier described the rectangular division of the garden and the ideal layout of square fields with different programs (Fig. 4), so that flat parts alternate with green volumes, sunny parts with shady ones, and so that elements do not recur next to each other on the sides of the axes. In this sense, very informed compositions are found in Slavkov u Brna or Český Krumlov (see Fig. 6 and 3). Compositional schemes of the gardens are organised by variously designed lines: Le Nôtre's realizations are interwoven with avenues, paths and clearings in the gardens or game parks, continuing to distances and inhabiting a wider landscape context. Also Dezallier (Dezallier, p. 30, p. 66-73) described their proper foundation so that they allowed views from the building into the distance or of a selected point de vue, but also their dimensions, maintenance and materials. Many examples can be found in the Czech Republic. The complex of villa with a garden, orchard and vineyard bound by a system of axes and interwoven by typical radial paths around the Sternberg Villa in Troja, which in the Baroque spirit dominates its surroundings and draws the close and distant views into its internal composition - the most significant one is the axial direction towards Hradčany (the Castle District), was created as early as after 1678. Although it is rather an Italian influence in the terraced disposition (Pacáková-Hoštálková, 2004), the connection with the surroundings points to French principles. Staying in Prague, a radial pattern of paths was created in the game reserve around the Renaissance Letohrádek Hvězda (Star Summer Palace) at the beginning of the 18th century. There are gardens where the rays form the outline of the entire garden, e.g. Červený Dvůr. After the mid-18th century, the Schwarzenbergs gradually built a Baroque garden of trapezoidal shape, with a central pool in the axis of the palace; the pool is the centre of eight rays. They divide the garden into bosquets and flat fields of triangular and irregular shapes. Their endings at the walls are highlighted by other water features. The lines in the form of a trident converging to the building of the palace and emphasising the main entrance, the so-called patte d'oie (goose foot), known in a generous scale from the Royal Garden at Versailles and others, was created in the Czech lands e.g. during the Baroque reconstruction of the palace in Krásný Dvůr. Clearings or avenues, often with the radial pattern, in game reserves or pheasantries, are associated with the popularity of hunting, in particular the so-called par force hunt, taken over from France. In the Baroque period, it represented one of the many activities and pastimes of the court and nobility.

The vast Lednice-Valtice Cultural Landscape with a highly unique scale is organized by a system of avenues, clearings and axes. Its space was structured by the Lichtenstein family in the Renaissance and the Baroque. Among others, the so-called Lednice star was created there as early as in 1692 (Dohnal 2014). It was a system of clearings in the game reserve, which were of a forest character rather than garden bosquets. According to new findings (Dohnal 2014, p. 35, 36), the later generous modifications of the turn of the 19th century followed up this stage of development of the territory very sensitively. These were the changes that made the area famous as a unique designed landscape of European scale.

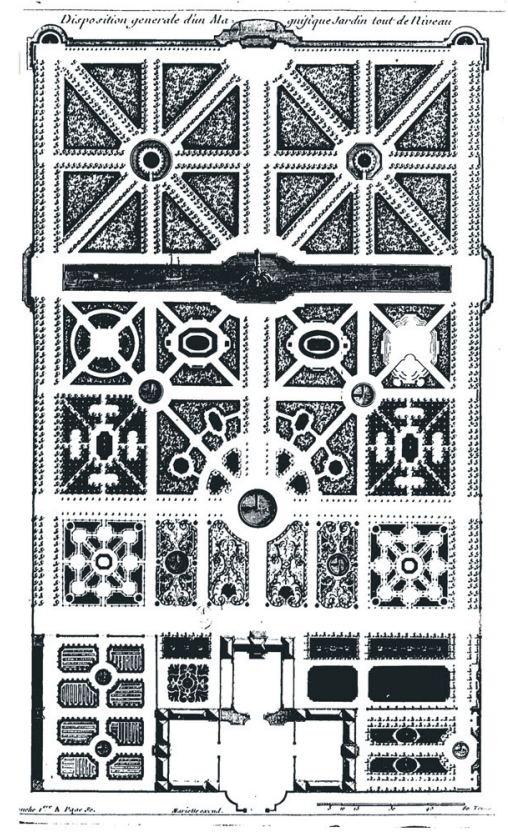

4: General disposition of a magnificient flat Garden, Dezallier d'Argenville, La théorie et pratique du jardinage (...), 1709. 


\section{Examples of significant garden complexes bearing the features of the French garden}

Besides the numerous palace and castle gardens, the Dobřís Chateau complex has a significant position. It was comprehensively described by Zdeněk Wirth (1938), who also put it in the context of garden design development. The chateau was finished (probably 1760, as indicated by Wirth 1938) in the second half of the 18th century, when the influence of France in our art had strengthened and besides the mediating effect of Vienna, was brought by direct employment of French artisans. Though Wirth's determination of the chateau authorship is debated ${ }^{10}$ today, the composition of the garden refers to the French prototype quite clearly and, as typical of the Czech territory, it is adapted to the local conditions, the owner's possibilities, the terrain configuration, and the position in respect to the town. The longitudinal axis uncharacteristically rises from the chateau and finishes with the building of orangery, which forms the chateau's counterweight of a similar width. The gentle slope is divided into terraces, the particular elevations are linked by ramps and stairs, the edges are decoratively broken and retaining walls are decorated by sculptures. The main axis has water features; the most impressive one that dominates the space is a water cascade with a sculptural group called Watering of Helios's Horses. The image of the time on the engraving by K. Saltzer (around 1770) (Fig. 5) shows shaped green walls architecturally forming the garden space and a rich parterre with ornamental flower beds, an overall decorativeness and diminution of decorations, typical of this late period and Rococo. As Wirth pointed out, the Dobřišs garden copies the garden layout of Schönbrunn and the topics of the sculptural decoration are similar too. It was created by a sculptor who studied in Vienna, Ignác Platzer. In contrast to the top French examples, the Dobřišs garden lacks the generous dimensions of the elongation of the main axis to infinity; however, it is consciously replaced by illusive paintings on the walls of the orangery.

The estates of the Kounic family in Slavkov u Brna carry both landscape architecture and urban planning features at the same time. The principles of axiality and bound composition captured at the so-called Petruzzi's plan of 1732 (Fig. 6) far exceed the limits of the garden, penetrate into the surrounding agricultural landscape and become a rectangular outline for the adjoining settlement. In addition, a spatial and volumetric composition reminiscent of French Versailles can be revealed (e.g. K. Krejčiříková, 2004); not only as regards particular elements, out of which the grand canal in the main axis and the sequence of terraces with water features and their interconnection most remind us of Le Nôtre's Royal Garden, but also the application of the rules of perspective: hiding and unexpectedly revealing views of specific spatial units, changing the impression of the actual size and distance in favour of monumentality and infinity.

Another example is the castle garden in Holešov, repeatedly characterized ${ }^{11}$ in the literature as an exceptionally intact example of a flat French garden of large scale in the Czech lands. Some researchers ${ }^{12}$ as well as this paper partly disprove this classification. Although there is no graphic

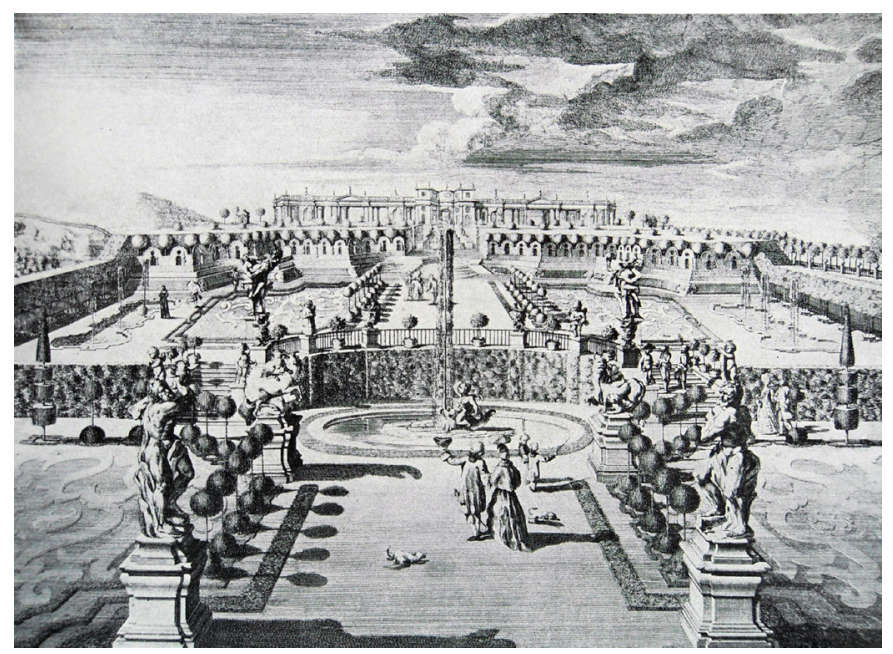

5: The Dobríš Chateau. Engraving by Karel Saltzer, by 1770.

10 The authors that Wirth declares, French royal architects Nicolas Servandonni and Jules Robert de Cotte, did not have any relation to the owner, according to Biegel $(2008$, p. 113, 114), so the author is probably another Frenchman, Stephan Dieudonné, representing the French Baroque and Neoclassicism in the Czech territory.

11 Wirth in his earlier publication of 1957, but also later; out of those influential and much referred to e.g. Pacáková-Hoštálková and her team of authors (2004).

12 E.g. Křesadlová in her lectures and presentations, Řezníček in his thesis (2014). 
documentation on the early phase of the garden, which accompanied the construction of the castle in the early Baroque style, some details of the layout visible in the oldest known plan of 1750 (Fig. 7) suggest that it is rather a garden of Dutch type: Our presumption is confirmed when comparing it with layouts of Dutch gardens, such as the gardens of the Manor House in the garden Sorghvliet or Hemstede ${ }^{13}$, both built in the context of flat agricultural landscapes - the garden itself is organized and bordered by water canals and the missing third dimension is replaced by carefully shaped live architecture of green walls and arcades. The enclosing water canal and pool in the centre of the Holešov garden were later complemented with a central canal in the castle axis (Řezníček, 2014), which stretches the layout into the distance, leads the view from the original central pool over the cascade up to the clearings in the adjacent game reserve and thus completes the massive water element to form a trident. Therefore, the plan from the mid-18th century (see Fig. 7) probably documents the garden after the adaptations in contrast to its original state, from the time of the castle completion or soon after (soon after 1650). The plan also shows other elements typical of the French garden: There is a detailed parterre with flower beds, its border as well as borders of other parts of the garden by shaped walls and arcades, a parterre of the orangery with a rich collection of potted plants, and radial clearings in the game reserve. However, specific examples of the geometric composition spilling out to the surrounding landscape (the direction of the main axis from the castle to the top of Hostýn hill is not confirmed, the axis only freely guides there) cannot be found, neither the magnificence of optical delusions (expressed by terrain modelling or green architecture), which would use the knowledge of perspective and affect the perception of the actual dimensions of the garden areas. The mentioned typical Dutch garden attributes, in this case the flat concept of the space and the canal flowing around the garden heart linked to the castle, form the main layout of the castle garden and remain legible despite the later stages of development and stylish changes even in the present.

\section{Remnants of French garden features in public urban spaces}

While in opposition to the French Baroque garden with a strictly bound form a new style developed in the context of enlightenment and Rousseau's philosophy - English landscape garden - some features and principles of the previous direction of garden design persisted: first, in utility gardens, and second, in a totally new urban form - public parks and promenades (Mosser 2002). Both newly established and private gardens ${ }^{14}$ newly opened to the public in European growing cities at the end of the 18th century still carried features of geometric division, they contained promenades and multiple avenues, boulingrins (bowling greens) and vast areas with plantings, which bore the signs of the formal style as can be found at Dézallier (Mosser, 2002, p. 105). The process of democratisation in France was manifested by making some gardens and promenades accessible for the public, e.g. The gardens of the Royal Palace in Paris (as early as in 1640) or the Tuileries Garden in 1672, shortly after their renovation based on Le Nôtre. As regards the environment close to Czech lands, the imperial Prater (1766) was opened in Vienna and slightly later Augarten (1775), the work of Le Nôtre's pupil Jean Trehet. An example of this trend in the Czech lands

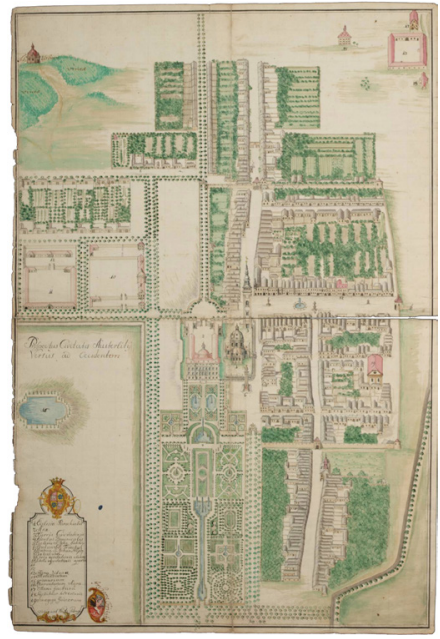

6: Slavkov u Brna, the so-called Petruzzi's plan.

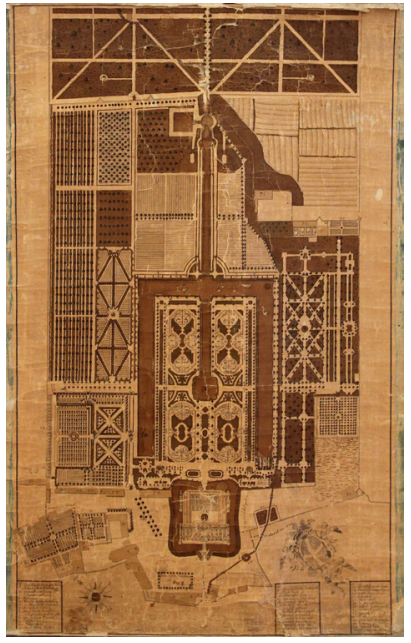

7: Castle and garden in Holešov, 1750.

13 Sorghvliet in the picture by Johannes van den Aveele (1691-1698); Hemstede in the province of Utrecht in the picture of Daniel Stopendael (1685-1702).

14 Among the first private royal gardens opened to the public were St. James's Park and Green Park in London (1635), followed by others in the other European cities around the mid-17th century (see Šafářová 2010). 
is the city park Lužánky in Brno, originally a Jesuit agricultural court that was dedicated to Brno citizens by the Emperor in 1786, after the dissolution of the order, so that a public town park could be established there. Two years later, its adaptation was finished - the park composition at this oldest stage of its existence was based on a network of rectangular axes defining squares with different programs and characters. The plans from the early 19th century ${ }^{15}$ still show the partially persistent geometric layout with a dominant main axis, based on the building of the courtyard (later casino), falling to the Ponávka stream and then climbing up to the opposite slope to a viewpoint.

\section{DISCUSSION}

Professional literature widely speaks about Baroque and Classicist gardens, but not always distinguishes the French provenance of garden design elements and overall composition. It came to the Czech lands in two main streams and in two ways. Less frequent and less documented is the direct way: work of Le Nôtre's disciples and French artists. One of them is the very significant Jaroměřice garden, which captures the area of irregular shape in an original way. The other way, via Vienna, brought a flatter and more decorative version of garden design. The distinction of the French influence is not always clear, especially where sufficient information about the authors, plans and documentation are missing. In these cases it is important to have personal experience with French gardens, knowledge of the overall relationships, not only individual elements. Therefore, the examples of gardens which reflect the prototype in more main features dominating the garden are emphasised, confirming that gardens of Jaroměříce, Slavkov, Dobříš and others fall into the sphere of French influence. Their affinity is supported by the individual motives and their groupings, the connection of the garden with its surroundings, and the work with the terrain. On the contrary, the common classification of the Holešov garden is disputed: when compared with French gardens, the Holešov garden lacks terrain modelling, distant views, and mainly, there is a different concept of the water canal motive, seeing the main inspiration in the Dutch type of garden.

However, to achieve the complexity of the French prototype, the Czech gardens lack the generous space, mastery of rules of perspective in favour of illusive perception of the real dimensions, and contrasting parts of the garden arising from terrain manipulation, in which sunny parterres alternate with shady bosquets, often surprisingly. There are several causes of the incomplete application of the French prototype. First, the period of absolute reign of the "Sun King" in France was a unique, unrepeatable circumstance, which had no parallel in the Czech lands, with their position as a part of the Habsburg Empire. Other reasons are undoubtedly the traditional artistic orientation to Italy and the geographical proximity and territorial affiliation to the Habsburg centre in Vienna, as well as the specific topography of the Czech lands, different from the flatter regions of France, where the prototype was formed. Noble families did not reach the power comparable with the French ruler; however, besides the representation through the palace buildings and gardens, they showed their influence through the spatial organisation of the more remote parts of their estates by avenues and linking by views. Landscape intensely colonized in this way, the so-called designed landscape, is quite unique, even within the European context.

\section{CONCLUSION}

The Baroque culture confirmed the garden as an integral part of the aristocratic residence; its organic interconnection with architecture developed also in the periods of late Baroque and classicism, garden and architecture together performed the representative function. According to Zdeněk Dokoupil and his team of authors, the mentioned principles developed in the Czech "landscape of small scale and mild expression" (Dokoupil et al., 1957, p. 20), Italian and French influences mixed and blended there. Neither the most significant city, the royal city, Prague, provided perfect topographical conditions for a complex application of the French type. Yet, in its territory partial forms used in the existing as well as newly established garden complexes can be found. Many intimate gardens with partial forms that were definitely inspired by the French environment were created outside Prague. Based on the presented overview of significant objects of garden design, the considerable position of the Czech lands in the European context can be confirmed. Very early examples of the Le Nôtre's principles of garden design are presented and the presence of French artists and creators active in the leading cultural centres is documented. The modifications occurred as a result of the mediation of the original prototype, but also the strong influence of the local landscape and local conditions. The French prototype did not develop in its entirety; its grandeur and magnificence, expressed through optical illusions, and play with perspective supported by shaped architecture of a vast scale

15 See the collection of vedutas of Brno stored in the collections of the Moravský zemský archiv (Territorial Archive of Moravia). 
were not applied in the Czech territory. However, it was significantly present in the typical features, individual forms, applied with understanding in garden complexes and the significant colonisation of landscape adjacent to the gardens.

\section{Acknowledgements}

The paper was created based on support for project DG16P02H053; The Czech Garden Design and Landscape Architecture in the Context of European Development, which meets thematic priority TP 1.4. of the Programme of Applied Research and Development of the National and Cultural Identity, funded by the Ministry of Culture of the Czech Republic.

\section{REFERENCES}

BARIDON, M. 2002. The Baroque Garden [in French: Les jardins de l'age baroque]. In: Le jardin à la francaise de la renaissance à nos jours. $1^{\text {st }}$ Edition. Dijon: Editions Faton, pp. 28-33.

BIEGEL, R. 2008. Between the Baroque and the Classicism. Tendencies and influences in the Czech architecture 1751-1790 [in Czech: Mezi barokem a klasicismem. Tendence a vlivy v české architektuře 1751-1790]. Dissertation Thesis. Prague: Charles University, Faculty of Philosophy, Department of Art History.

BOUCHENOT-DÉCHIN, P. and FARHAT, G. 2013. André Le Nôtre in perspectives [in French: André Le Nôtre en perspectives]. Hazan: Malakoff Cedex.

DOHNAL, J. 2015. Artistic, architectural and landscape contexts of Lednice-Valtice Area and their changes in time [in Czech: Výtvarné, architektonické a krajinářské souvislosti Lednicko-valtického areálu a jejich proměny v čase]. Dissertation Thesis. Mendel University in Brno, Faculty of Horticulture, Department of Garden Design and Landscape Architecture.

DOKOUPIL, Z., NAUMANN, P., RIEDL, D. et al. 1957. Historical Gardens in Bohemia and Moravia [in Czech: Historické zahrady v Čechách a na Moravẻ]. $1^{\text {st }}$ Edition. Praha: Nakladatelství československých výtvarných umělců.

HATTON, R. 2001. George I. $1^{\text {st }}$ Edition. New Haven and London: Yale University Press.

KREJČIŘÍKOVÁ, K. 2004. Austerlitz - Rediscovery and renewal of a part of an old baroque structure of the park [in Czech: Slavkov - znovuobjevení a obnova části staré barokní struktury parku]. In: Historické zahrady Kromèríz 2004. Uméní a společenská činnost v historických zahradách. Hrdějovice: Agentura Bonus, pp. 37-39.

KROUPA, J. 2004. History and theory of garden art [in Czech: Déjiny a teorie zahradního umèní]. Brno: Faculty of Arts, Masaryk University.

KROUPA, J. 2006. Dietrichstein's Gardens in Moravia in the $18^{\text {th }}$ Century [in Czech: Dietrichsteinské zahrady na Moravě v 18. století]. In: Historickézahrady Kromérǐ̌z 2006. Umèní a společenská činnost v historických zahradách. Hrdějovice: Agentura Bonus, pp. 65-67.

KRSEK, I., KUDĚLKA, Z., STEHLÍK, M. et al. 1996. The Baroque Art in Moravia and Silesia [in Czech: Umèní baroka na Moravě a ve Slezsku]. $1^{\text {st }}$ Edition. Praha: Academia.

MERTENOVÁ, K. 2011. Penetration of the English Park into the French Garden [in Czech: Pronikáníanglického parku do francouzskézahrady véeských zemích]. Dissertation Thesis. Czech Technical University in Prague, Faculty of Architecture, Department of Theory and History of Architecture.

MOSSER, M. 2002. Formal Gardens in the $18^{\text {st }}$ century [in French: Les jardins réguliers au dix-huitième siècle]. In : Le jardin à la francaise de la renaissance à nos jours. $1^{\text {st }}$ Edition. Dijon: Editions Faton, pp. 98-104.

PACÁKOVÁ-HOŠŤÁLKOVÁ, B. and PETRŮ, J. 2004. Gardens and parks in Bohemia, Moravia and Silesia [in Czech: Zahrady a parky v Čechách, na Moravě a ve Slezsku]. $2^{\text {nd }}$ Edition. Praha: Libri.

PAVLÁTOVÁ, M. 2004. Gardens and parks of South of Bohemia [in Czech: Zahrady a parky jižních Čech]. ${ }^{\text {st }}$ Edition. Praha: Společnost pro zahradní a krajinářskou tvorbu.

POCHE, E. 1989. Architecture of the Late Baroque and Rococo in Bohemia [in Czech: Architektura pozdního baroka a rokoka v Čechách].In: Déjiny českého výtvarného umèníII/2.1 ${ }^{\text {st }}$ Edition. Praha: Academia, pp. 662-710.

ŘEZNÍČEK, M. 2014. Reconstruction of Chosen Historical Gardens in Moravia [in Czech: Rekonstrukce vybraných historických zahrad na Moravè. Promèny metodických prístupi státní památkové péće v letech 1950-2010]. Diploma Thesis. Palacký University Olomouc, Faculty of Arts, Department of Art History.

ŠAFÁŘOVÁ, L. 2010. Evaluation of Landscape Architecture and Garden Art of the $19^{\text {th }}$ Century focusing on City Parks [in Czech: Zhodnocení krajinář́sé architektury a zahradního uméní v 19. století se zamérením na méstské parky]. Dissertation Thesis. Mendel University in Brno, Faculty of Horticulture, Department of Garden Design and Landscape Architecture.

ŠUBR, J. 2004. On the Evolution of the Park in Židlochovice [in Czech: K vývoji zámeckého parku v Židlochovicích]. In: Historickézahrady Kromérú̌ 2004. Vývoj zahradní kultury. Hrdějovice: Agentura Bonus, pp. 27-28.

WIRTH, Z. 1911. European garden [in Czech: Evropská zahrada]. Praha: Svaz čes. spolků pro okrašlování a ochranu domoviny.

WIRTH, Z. 1938. Castle of Dobřî́s [In Czech: Dobříšský zámek]. In: Umèní XI, pp. 57-75. 


\section{Contact information}

